\begin{abstract}
Iranica
Abstracta Iranica Revue bibliographique pour le domaine irano-aryen

Volume 34-35-36 | 2017

Comptes rendus des publications de 2011-2013
\end{abstract}

\title{
Rudolph H. Dornemann. The Qarqur challenge: Middle Islamic through Iron Age
}

\section{Astrid Nunn}

\section{(2) OpenEdition}

1 Journals

\section{Édition électronique}

URL : http://journals.openedition.org/abstractairanica/41595

DOI : 10.4000/abstractairanica.41595

ISSN : 1961-960X

Éditeur :

CNRS (UMR 7528 Mondes iraniens et indiens), Éditions de l'IFRI

Référence électronique

Astrid Nunn, «Rudolph H. Dornemann. The Qarqur challenge: Middle Islamic through Iron Age », Abstracta Iranica [En ligne], Volume 34-35-36 | 2017, document 46, mis en ligne le 15 juillet 2016, consulté le 02 octobre 2020. URL : http://journals.openedition.org/abstractairanica/41595 ; DOI : https://doi.org/ 10.4000/abstractairanica.41595

Ce document a été généré automatiquement le 2 octobre 2020.

Tous droits réservés 


\title{
Rudolph H. Dornemann. The Qarqur challenge: Middle Islamic through Iron
} Age

\author{
Astrid Nunn
}

\section{RÉFÉRENCE}

Rudolph H. Dornemann. « The Qarqur challenge: Middle Islamic through Iron Age ». Near Eastern Archaeology, 75/3, 2012, p. 162-176.

1 Après avoir travaillé sur la Jordanie, l'A. a fouillé plusieurs sites en Syrie. Le dernier est Tell Qarqur qui correspond au Qarqar des Annales des rois assyriens Salmanassar III et Sargon II. Les couches islamiques, byzantines, romaines et hellénistiques avaient déjà été fouillées dans les années 1980 et 1990 . Sous les couches hellénistiques apparurent des constructions achéménides et du Fer II de fonction indéterminée. Elles étaient accompagnées de «cavaliers perses» et de plaquettes à femme nue souvent dénommées « Astarté ».

\section{AUTEURS}

\section{ASTRID NUNN}

Université de Munich 